\title{
Ineffective health management in hemodialysis patients: content analysis
}

\author{
Autocontrole ineficaz da saúde em pacientes em hemodiálise: análise de conteúdo \\ Mantenimiento ineficaz de la salud en pacientes en hemodiálisis: análisis de contenido
}

\section{Maria das Graças Mariano Nunes de Paiva', Jéssica Dantas de Sá Tinôco', Fernanda Beatriz Batista Lima e Silva', Juliane Rangel Dantas', Marcos Venícios de Oliveira Lopes", Ana Luisa Brandão de Carvalho Lira'}

' Universidade Federal do Rio Grande do Norte. Natal, Rio Grande do Norte, Brazil. "Universidade Federal do Ceará. Fortaleza, Ceará, Brazil.

\author{
How to cite this article: \\ Paiva MGMN, Tinôco JDS, Silva FBBL, Dantas JR, Lopes MVO, Lira ALBC. Ineffective health management \\ in hemodialysis patients: content analysis. Rev Bras Enferm [Internet]. 2017;71(4):1825-31.
}

DOI: http://dx.doi.org/10.1590/0034-7167-2016-0682

Submission: 10-02-2017 Approval: 03-07-2017

\begin{abstract}
Objective: To analyze the content of the nursing diagnosis Ineffective Health Management in hemodialysis patients. Method: The Nursing Diagnoses Validation Model by Lopes, Silva and Auraújo was used in this research. A semi-structured questionnaire and evaluated the definition, location, defining characteristics, and related factors of the diagnosis Ineffective Health Management was answered by 22 experts in nursing diagnosis. The analysis was conducted from August 2014 to January 2015. Results: Experts considered the proposed definition and the current location in the taxonomy II by the NANDA-I, Domain 1 Health Promotion, Class 2 Health Control, adequate to the diagnosis. The adequacy level adopted at $85 \%$ or $p>0.05$ were above 10 defining characteristics and 24 related factors. Experts also suggested that one defining characteristic should become a related factor and that three factors should turn into defining characteristics. Conclusion: A new proposal was developed for the diagnosis under study after the analysis of experts.
\end{abstract}

Descriptors: Validation Studies; Nursing Diagnosis; Renal Dialysis; Taxonomy; Nursing.

\section{RESUMO}

Objetivo: Analisar o conteúdo do diagnóstico de enfermagem Autocontrole ineficaz da saúde em pacientes em hemodiálise. Método: O Modelo de Validação de Diagnóstico de Enfermagem por Lopes, Silva e Araújo foi usado nesta pesquisa. Um questionário semiestruturado foi respondido por 22 especialistas em diagnóstico de enfermagem e, avaliou a definição, localização, características definidoras e fatores relacionados do diagnóstico Autocontrole ineficaz da Saúde. A análise foi realizada de agosto de 2014 a janeiro de 2015. Resultados: Os especialistas consideraram como adequada ao diagnóstico, a definição proposta e a localização atual na taxonomia II da NANDA-I, promoção de saúde do domínio 1, controle de saúde na classe 2. O nível de adequação adotado foi superior a $85 \%$ ou $p>0,05$ para 10 características definidoras e 24 fatores relacionados. Especialistas também sugeriram que uma característica definidora deveria se tornar um fator relacionado e que três fatores devem se transformar em características definidoras. Conclusão: Uma nova proposta foi desenvolvida para o diagnóstico em estudo após a análise de especialistas.

Descritores: Estudos de validação; Diagnóstico de Enfermagem; Diálise Renal; Taxonomia; Enfermagem.

\section{RESUMEN}

Objectivo: Analizar el contenido del diagnóstico de enfermería Mantenimiento Ineficaz de la Salud en pacientes en hemodiálisis. Método: El modelo de validación de diagnóstico de enfermería de Lopes, Silva y Auraújo fue utilizado en esta investigación. Un cuestionario semiestructurado que evaluó la definición, ubicación, características definitorias y factores relacionados con el diagnóstico Mantenimiento Ineficaz de la Salud fue respondido por 22 expertos en diagnóstico de enfermería. El análisis se realizó entre agosto de 2014 y enero de 2015. Resultados: Los expertos consideraron la definición propuesta y la ubicación 
actual en la taxonomía II de NANDA-I, Dominio 1 Promoción de Salud, Clase 2 Control de Salud, como adecuada para el diagnóstico. El nivel de adecuación adoptado fue $85 \%$ o p > 0.05 estaba por encima de diez características definitorias y 24 factores relacionados. Los expertos también sugirieron que una característica definitoria debería convertirse en un factor relacionado y que tres factores deberían convertirse en características definitorias. Conclusión: Se desarrolló una nueva propuesta para el diagnóstico en estudio después del análisis de expertos.

Descriptores: Estudios de Validación; Diagnóstico de Enfermería; Diálisis Renal; Taxonomía; Enfermería.

\section{INTRODUCTION}

The validation of a nursing diagnosis (ND) has three stages, namely: concept analysis, content analysis by experts, and accuracy of clinical indicators ${ }^{(1)}$. Assessment conducted by experts in ND contributes to make decision-making more reliable, accurate, and positive in nursing care $^{(2)}$.

The clientele undergoing hemodialysis experiences frequent changes Which require require significant control in everyday life. Patients are subject to water and food restriction, strict drug therapy and continuous hemodialysis. Thus, the difficulty to adhere to treatment becomes more apparent in this population, giving rise to negative feelings related to limitations imposed by disease, and affecting well-being at the biopsychosocial level ${ }^{(3)}$. The ND in the NANDA-I that is most suited to individuals who do not effectively adhere to therapy is Ineffective Health Management (00078).

This ND belongs to the domain health promotion, in the health management class, and is defined as "pattern of regulating and integrating into daily living a therapeutic regimen for the treatment of illness and its after-effect that are unsatisfactory for meeting specific health goals"(4).

A previous study conducted a conceptual analysis of the ND Ineffective Health Management in patients undergoing hemodialysis proposed to redefine this ND as "patient's inability to control habits and achieve therapeutic targets agreed with professionals, resulting in health complications" ${ }^{\prime \prime 5}$. Identified related factors were: poor knowledge; inadequate use of medications; non-adherence to water restriction; chronic sadness; sociodemographic factors; deficient social support network; non-adherence to treatment; beliefs; economic difficulties; lack of motivation; negative psychological state; miscommunication; non-adherence to food restriction; treatment complexity; anxiety; comorbidities; self-efficacy; lack of emotional support; lack of fistula care/vascular access; maladjustment to new conditions; irregular attendance to dialysis sessions; lack of transport to attend dialysis sessions; treatment dropout; negative self-image; health policy; neurocognitive dysfunction; negotiation failure; inadequate dialysis; ill-defined treatment plan; asymptomatic nature of disease; fistula puncture pain; identification of barriers to change; and lack of planning.

The defining characteristics proposed ${ }^{(5)}$ were: high interdialytic weight gain; quality of life; longer length of hospitalization; severe complications of kidney disease; low self-esteem; changes in laboratory tests; fatigue; increased symptoms; lack of treatment; change in treatment time; emergency care; infection; increased cost of treatment; fistula issues; difficult fluid removal during hemodialysis; and treatment dropout. However, content analysis was not validated.
Studies identified ND in hemodialysis patients and Ineffective Health Management were rated in different frequencies by the authors ${ }^{(6-8)}$. Such difference may indicate the need to further analyze ND, providing components that best characterize the ND in specific patients. Therefore, content analysis by experts should be conducted after concept analysis, and it is important for the understanding of diagnosis in the context it is inserted.

Therefore, validation studies contribute to diagnostic accuracy, planning of appropriate interventions, positive health outcomes for the individual, family, community, and brings important contribution to nursing as a science.

Given these factors, the guiding question of this research was: "Are the components of the Nursing Diagnosis Ineffective Health Management detected in the hemodialysis clientele?" Thus, this study consists in a content analysis of the ND Ineffective Health Management in hemodialysis patients.

From this perspective, the process aims to favor the identification of ND components (definition, defining characteristics, related factors, and empirical definitions) in order to meet the actual individual needs and to provide faster identification of nursing issues, proposing consistent, safe, and effective goals, contributes to systematize a problem-solving nursing care.

\section{OBJECTIVE}

To analyze the content of the nursing diagnosis Ineffective Health Management in hemodialysis patients.

\section{METHOD}

\section{Ethical aspects}

Study approved by the Research Ethics Committee of the Federal University of Rio Grande do Norte (UFRN) and the Certificate of Submission for Ethical Assessment (CSEA), complying with the Resolution 466/2012 of the Brazilian National Health Council (CNS) ${ }^{(9)}$.

\section{Designs}

Content analysis conducted by experts in ND, based on the second stage proposed in the Nursing Diagnoses Validation Model $^{(1)}$, tested the adequacy of components proposed to the ND Ineffective Health Management ${ }^{(5)}$.

\section{Sample}

The sample consisted of 22 experts in ND, estimated by using the formula: $\mathrm{n}=\mathrm{Z} \infty 2 * \mathrm{P} *(1-\mathrm{P}) / \mathrm{e} 2$, where " $\mathrm{Z} \infty$ " indicates the confidence level (95\%) and the value adopted (1.96); " $P$ " is 
the expected percentage of experts indicating the suitability of each item (85\%); and " $\mathrm{e}$ " represents the acceptable proportional difference from the results expected $(15 \%)^{(1)}$.

\section{Inclusion and exclusion criteria}

Experts were selected based on the Brazilian National Council of Technological and Scientific Development (CNPq) Lattes Platform. Expert inclusion criteria were to be clinically experienced in hemodialysis; and have published studies on nursing diagnoses. All experts with this profile were selected.

\section{Study protocol}

The analysis was conducted from August 2014 to January 2015. Initially, the number of experts selected was above the sampling calculation, due to the possibility of failure to make contact, refusal to participate, and incomplete information. Therefore, an invitation letter was sent by email to 37 experts selected according to the inclusion criteria. The result was, 3 (8.1\%) did not accept to participate in the study and $12(32.4 \%)$ did not send complete information (after 3 attempts), totaling 22 experts (59.5\%).

After acceptance to participate in the research, each expert received, via email, a free and informed consent term, with general information about the study. This document was then signed, scanned, and sent back to the researcher. Next, a data collection instrument was sent to each participant expert.

The instrument consisted of a two-part semistructured questionnaire: the first on identification data and expert experience, and the second on validation of the ND Ineffective Health Management (definition, location, defining characteristics, and related factors). Experts were asked to rate on a five-level Likert scale: 1) no indicative/relevant; 2) very little indicative/ relevant; 3) somewhat indicative/relevant; 4) very indicative/relevant; and 5) extremely indicative/ relevant. The items classified as 1, 2, or 3 were grouped as inadequate and the items classified into 4 or 5 were grouped as adequate, recording the data as dichotomous.

\section{Analysis of results}

All data was processed using the software Microsoft Excel ${ }^{\circledR}$, 2010 version. The analysis was performed using the Statistical Package for the Social Sciences ${ }^{\circledR}$ (SPSS), 16.0 version, resorting to a binomial test to determine the proportion of experts who indicate that each adequate item was not below $85 \%$. For that, the significance level adopted was $5 \%$, with $p>$ 0.05 , and the adequate item was above $85 \%$. Consequently, the components that did not show these proportions were excluded from the final proposal of the ND Ineffective Health Management.

\section{RESULTS}

The 22 experts selected to evaluate the ND Ineffective Health Management are characterized in Table 1.

In $2016,91 \%$ of the participants worked in educational institutions and $86.4 \%$ taught ND, $63.3 \%$ reported to provide care to hemodialysis patients or those with the ND Ineffective Health Management, and $45.5 \%$ reported practical identification of this ND in few cases.
Table 1 - Characterization of experts selected to participate in the study

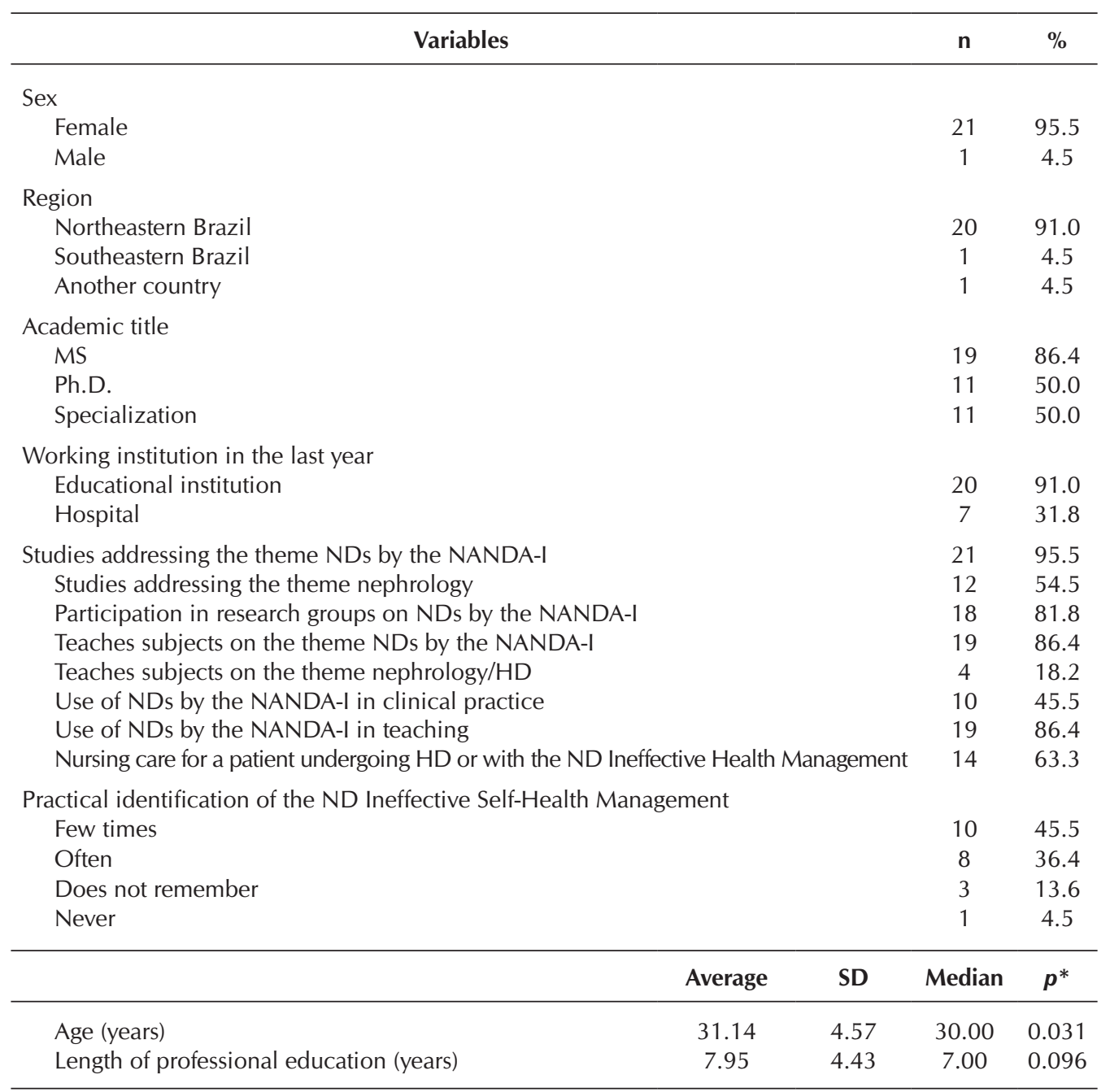

Note: $N D=$ Nursing diagnosis; $H D=$ hemodialysis; $S D=$ standard deviation; ${ }^{*}=$ Kolmogorov-Smirnov test . 
Table 2 - Adequacy of the clinical indicators of the nursing diagnosis Ineffective Health Management

\begin{tabular}{lccc}
\hline \multicolumn{1}{c}{ Defining characteristics } & $\mathbf{n}$ & $\mathbf{\%}$ & $\boldsymbol{p}^{*}$ \\
\hline Expressed difficulty with prescribed regimens & 22 & 100.0 & 1.000 \\
Daily life choices ineffective to achieve health goals & 21 & 95.5 & 0.972 \\
Intensified complications of chronic kidney disease & 21 & 95.5 & 0.972 \\
Changes in laboratory tests & 20 & 90.9 & 0.863 \\
Increased effects of the symptoms & 20 & 90.9 & 0.863 \\
Seeking emergency services & 20 & 90.9 & 0.863 \\
High interdialytic weight gain (over 2 kg) & 19 & 86.4 & 0.661 \\
Infection & 19 & 86.4 & 0.661 \\
Expressed wish to control the disease & 17 & 77.3 & 0.226 \\
Quality of life & 16 & 72.7 & 0.099 \\
Treatment dropout & 13 & 59.1 & 0.002 \\
Failure to act to reduce risk & 12 & 54.5 & 0.000 \\
Non-attendance to treatment & 12 & 54.5 & 0.000 \\
Problem with the fistula & 12 & 54.5 & 0.000 \\
Low self-esteem & 11 & 50.0 & 0.000 \\
Prolonged hospitalizations & 11 & 50.0 & 0.000 \\
Difficult fluid removal during hemodialysis & 11 & 50.0 & 0.000 \\
Changes in treatment time & 9 & 40.9 & 0.000 \\
Excessive stress & 9 & 40.9 & 0.000 \\
Increased treatment costs & 8 & 36.4 & 0.000 \\
Fatigue & 8 & 36.4 & 0.000 \\
\hline
\end{tabular}

Note: * Binomial test.

Table 3 - Evaluation of the adequacy of factors related to the nursing diagnosis Ineffective Health Management

\begin{tabular}{llll}
\hline \multicolumn{1}{c}{ Related factors } & $\mathbf{n}$ & $\boldsymbol{\%}$ & $\boldsymbol{p}^{*}$ \\
\hline Complexity of the therapeutic regimen & 21 & 95.5 & 0.972 \\
Poor knowledge & 21 & 95.5 & 0.972 \\
Failure to communicate & 21 & 95.5 & 0.972 \\
Lack of motivation & 21 & 95.5 & 0.972 \\
Failure to adapt to new conditions & 21 & 95.5 & 0.972 \\
Irregular attendance to hemodialysis sessions & 20 & 90.9 & 0.863 \\
Lack of planning & 20 & 90.9 & 0.863 \\
Lack of emotional support & 20 & 90.9 & 0.863 \\
Non-adherence to treatment & 20 & 90.9 & 0.863 \\
Asymptomatic nature of disease & 20 & 90.9 & 0.863 \\
Time spent on hemodialysis sessions & 20 & 90.9 & 0.863 \\
ExInappropriate use of medications & 20 & 90.9 & 0.863 \\
Comorbidities & 19 & 86.4 & 0.661 \\
Withdrawal from goals & 19 & 86.4 & 0.661 \\
Neurocognitive dysfunction & 19 & 86.4 & 0.661 \\
Perceived severity & 19 & 86.4 & 0.661 \\
Negative self-image & 18 & 81.8 & 0.424 \\
Beliefs & 18 & 81.8 & 0.424 \\
Previous experiences & 18 & 81.8 & 0.424 \\
Socioeconomic factor & 18 & 81.8 & 0.424 \\
Chronic sadness & 17 & 77.3 & 0.226 \\
Anxiety & 16 & 72.7 & 0.099 \\
Perceived benefits & 16 & 72.7 & 0.099 \\
Residual renal function & 16 & 72.7 & 0.099 \\
Obesity & 15 & 68.2 & 0.036 \\
Pain to puncture in arteriovenous fistula & 13 & 59.1 & 0.002 \\
Poor social support network & 13 & 59.1 & 0.002 \\
Identification of barriers to changes & 12 & 54.5 & 0.000 \\
Family conflict & 11 & 50.0 & 0.000 \\
\hline
\end{tabular}

Regarding the definition of the ND Ineffective Health Management, the experts were informed about the current taxonomy II by the NANDA-I, having the concept analysis by Silva (2013) as a basis; $54.5 \%$ of the experts claimed that the author provided the most appropriate definition for this ND: "Patient's inability to control habits and achieve the therapeutic goals agreed with professionals, resulting in health complications"(5).

As for the location of the ND Ineffective Health Management, two positions were pointed out: Domain 1: Health Promotion and Class 2: Health Control, current location of the ND in the taxonomy II by the NANDA-I; and Domain 1: Health Promotion and Class 1: Health Perception, addressed by the concept analysis. In this case, $100 \%$ of the experts regarded the current location of this ND as adequate.

The 22 experts evaluated the clinical indicators of the ND Ineffective Health Management in the taxonomy II by the NANDA-I (Table 2).

The defining characteristics below the adequacy level adopted ( $85 \%$ or $p>0.05$ ) were removed from the ND Ineffective Health Management; thus, 11 clinical indicators of this ND were excluded from the concept analysis.

Regarding the title of defining characteristics, some experts also suggested changes, namely: "Intensified complications of chronic kidney disease" becomes "Intensified complications of disease;" "Quality of life" becomes "Impaired quality of life;" "Increased effects of symptoms" becomes "Intensified symptoms of disease;" "Seeking emergency services" becomes "Often seeking hospital services;" and "Expressed wish to control the disease" becomes "Non-expressed wish to control the disease." It was suggested that "Often seeking hospital services" was assigned to factors related to the ND under study. The suggestions were regarded as pertinent, therefore, accepted.

The 22 experts evaluated the adequacy of factors related to the ND under study (Table 3).

The related factors that showed a concordance index below $85 \%$ or $p<0.05$ were excluded. Thus, there were 22 related factors taken from the ND Ineffective Health Management.

The experts were asked about the most appropriate nomenclature for two related factors found in the concept analysis that were similar to those provided by the NANDA-I: "Poor knowledge" vs. "Knowledge deficit" and "Identification of barriers to changes" $\mathrm{x}$ "Perceived barriers." Therefore, $72.7 \%$ of the experts considered the term "Poor knowledge" as the most appropriate and 54.5\% considered "Perceived barriers" as the most pertinent. 


\begin{tabular}{lccc}
\hline \multicolumn{1}{c}{ Related factors } & $\mathbf{n}$ & \% & $\boldsymbol{p}^{*}$ \\
\hline Excessive demands & 11 & 50.0 & 0.000 \\
Sexual dysfunction & 11 & 50.0 & 0.000 \\
Poor transport to hemodialysis & 11 & 50.0 & 0.000 \\
Poorly defined treatment plans & 11 & 50.0 & 0.000 \\
Financial problems & 11 & 50.0 & 0.000 \\
Negative psychological status & 10 & 45.5 & 0.000 \\
Lack of fistula care & 10 & 45.5 & 0.000 \\
Dialysis inadequacy & 10 & 45.5 & 0.000 \\
Non-adherence to food restrictions & 10 & 45.5 & 0.000 \\
Break with basic human needs & 10 & 45.5 & 0.000 \\
Non-adherence to water restriction & 9 & 40.9 & 0.000 \\
Poor negotiation & 9 & 40.9 & 0.000 \\
Family patterns of health care & 9 & 40.9 & 0.000 \\
Self-efficacy & 8 & 36.4 & 0.000 \\
Perceived susceptibility & 8 & 36.4 & 0.000 \\
Inadequate number of clues to action & 7 & 31.8 & 0.000 \\
Health policies & 7 & 31.8 & 0.000 \\
\hline Note: Bing & & & \\
\hline
\end{tabular}

Note: * Binomial test. Source: Prepared by the authors.

The experts suggested to change the terminological level of related factors: "Sociodemographic factor" becomes "Unfavorable sociodemographic factor;" "Inappropriate use of medications" becomes "Inappropriate use of drugs;" "Negative self-image" becomes "Negative body image;" "Previous experiences" becomes "Negative previous experiences;" "Perceived benefits" becomes "Nonperceived benefits;" "Perceived severity" becomes "Non-perceived disease severity." They also suggested to turn "Inappropriate use of medications," "Non-adherence to treatment," and "Irregular attendance to hemodialysis sessions" into defining characteristics. The suggestions were regarded as pertinent, therefore, accepted.

Chart 1, displays the final proposal for the ND Ineffective Health Management, having the findings of this study as a basis.

Chart 1 - Final proposal for the nursing diagnosis Ineffective Health Management

\begin{tabular}{|l|l|}
\hline \multicolumn{1}{|c|}{ Defining characteristics } & \multicolumn{1}{|c|}{ Related factors } \\
\hline Changes in laboratory tests & Anxiety \\
Irregular attendance to dialysis sessions & Unperceived benefits \\
High interdialytic weight gain (over $2 \mathrm{~kg}$ ) & Seeking hospital services \\
Daily life choices ineffective to achieve health goals & Comorbidities \\
Expression of difficulty with the treatment prescribed & Treatment complexity \\
Infection & Poor knowledge \\
Intensified disease complications & Beliefs \\
Intensified disease symptoms & Treatment dropout \\
Non-adherence to treatment & Neurocognitive dysfunction \\
Non-expressed wish to control the disease & Negative previous experiences \\
Impaired quality of life & Failure to communicate \\
Inappropriate use of medications & Lack of motivation \\
& Lack of planning \\
& Lack of emotional support \\
& Unfavorable sociodemographic factor \\
& Residual kidney function \\
& Negative body image \\
& Maladjustment to new conditions \\
& No perception of disease severity \\
& Asymptomatic nature of disease \\
& Time spent on hemodialysis \\
& Chronic sadness \\
\hline
\end{tabular}

\section{DISCUSSION}

Content analysis of the ND Ineffective Health Management with regard to hemodialysis patients contributes to improve nursing care, by providing professionals with a refined taxonomy, making this ND more reliable.

The experts evaluated the adequacy of the ND clinical indicators having knowledge acquired through professional, clinical, or academic experience as a basis. The characterization of study participants is similar to other studies conducted to validate nursing classifications $\mathbf{s}^{(5,10-12)}$. It is worth noticing that experts were selected considering their academic titles, studies, and clinical experience with the theme addressed ${ }^{(13)}$.

The definition of a ND must be clear and concise, in order to make decisionmaking and communication easier in the nursing team ${ }^{(4)}$. Therefore, the experts chose the definition proposed having concept analysis as a basis. In terms of location, the experts chose the Domain 1: Health Promotion and Class 2: Health Control. The domain Health Promotion is defined as "perception of well-being or normal function and strategies used to keep control of this well-being and normal function, as well as to improve them," and the class Health Control consists in "identification, control, performance, and interconnection of activities to maintain health and well-being"(4).

To establish effective health control, hemodialysis patients have to adhere to treatment. It is known that this clientele tend to comply with treatment, which is decisive for survival, but not as a comprehensive practice, due to several factors, such as: waking up early; distance between the household and the clinic; transport issues; frequency and time devoted to hemodialysis; pain or discomfort in arteriovenous fistula puncture; arteriovenous fistula care; financial, psychological, nutritional, and cultural factors; complex therapy; water restriction; dependency on caregivers; poor knowledge; social role; and educational level ${ }^{(14-15)}$.

It is essemtial that individuals undergoing hemodialysis adapt to a new lifestyle. Their chances of survival include water and food restrictions, drug therapy, limited ability to fulfill daily life activities, in addition to getting connected to a machine during the hemodialysis session, over four hours, three times a week.

Furthemore, catheter or arteriovenous fistula are used, the patients are connected to a machine and their body 
changes, making her/him insecure and fearful regarding body image $^{(16)}$. This often gives rise to emotional issues that culminate in low self-esteem, anxiety, and depression in this clientele ${ }^{(17-18)}$. Moreover, poor knowledge on self-care is an intrinsic factor for non-adherence to treatment and ineffective health care ${ }^{(19-20)}$. Chronic kidney disease derives from metabolic complications and comorbidities, resulting in multiple use of drugs ${ }^{(21)}$.

A study reveals that when the patient accepts the treatment, complying with diet and medication prescriptions, lower is the chance of complications related to disease and treatment ${ }^{(22)}$. In addition to knowledge and discipline, hemodialysis patients need to be supported by family members and friends, as well as the health team. The support network has a positive impact on the hemodialysis clientele $\mathrm{e}^{(23-24)}$.

From this perspective, content analysis of the ND Ineffective Health Management provides significant knowledge for nursing professionals, which enabling them to identify the indicators with greater accuracy and clarity and facilitates decision-making and communication in the nursing team.

\section{Study limitations}

Methodological limitations of this research consist in the extension of the instrument's items, and slowness of responses. Therefore, it is worth mentioning the possibility of more objective instruments and other methodological approaches to be used with these experts. Another limitation is related to the study design, since only experts on the Lattes Platform were selected and there was a single round to collect the data. For that rreason, other methodological approaches could be used with these experts, such as the Delphi method.

\section{Contributions to nursing}

We hope that the findings of this study contribute to the clinical validation of the ND concerned.

\section{CONCLUSION}

The final proposal for the ND Ineffective Health Management, having content analysis by experts as basis, considered adequate the proposed definition and the current location in the taxonomy II by the NANDA-I, Domain 1 (Health Promotion), Class 2 (Health Control).

The proposed definition for nursing diagnosis of Ineffective Health Management, based on the opinion of experts was: Patient's inability to control habits and achieve therapeutic goals agreed with professionals, resulting in health complications.

The experts regard 12 defining characteristics as adequate, namely: Expressed difficulty with prescribed regimens; Daily life choices ineffective to achieve health goals; Intensified complications of disease; Changes in laboratory tests; Intensified symptoms of disease; High interdialytic weight gain (over $2 \mathrm{~kg}$ ); Infection; Non-expressed wish to control the disease; Impaired quality of life; Irregular attendance to hemodialysis sessions; Non-adherence to treatment; And Inappropriate use of drugs.

The adequacy of 22 related factor is indicated, they are: Complexity of the therapeutic regimen; Poor knowledge; Failure to communicate; Failure to adapt to new conditions; Lack of motivation; Lack of planning; Lack of emotional support; Asymptomatic nature of disease; Time spent on hemodialysis sessions; Comorbidities; Withdrawal from goals; Neurocognitive dysfunction; Non-perceived disease severity; Negative body image; Beliefs; Negative previous experiences; Unfavorable sociodemographic factor; Chronic sadness; Anxiety; Non-perceived benefits; Residual kidney function; And Often seeking hospital services.

The results of this study can contribute to the adequate application of the ND Ineffective Health Management and support clinical validation studies. It also brings important contribution to nursing as a science.

Hence, clinical validation is recommended to identify the accuracy of the defining characteristics and contribute to the diagnosis judgment of the nurse, in order to address more clearly the care provided to patients.

\section{FUNDING}

This study received funding from the Brazilian National Council of Technological and Scientific Development (CNPq), through the Grant 477559/2013-1.

\section{REFERENCES}

1. Lopes MVO, Silva VM, Araújo TL. Methods for Establishing the Accuracy of Clinical Indicators in Predicting Nursing Diagnoses: NANDA International. Int J Nurs Knowl[Internet]. 2012[cited 2015 Jun 10];23(3):134-9. Available from: https://www.ncbi.nlm. nih.gov/pubmed/23043652

2. Moreira RP, Guedes NG, Lopes MVO, Cavalcanti TF, Araújo TL. Diagnóstico de enfermagem estilo de vida sedentário: validação por especialistas. Texto Contexto Enferm[Internet]. 2014[cited 2015 Jun 10]. Available from: http://www.scielo.br/pdf/tce/v23n3/ pt_0104-0707-tce-2014000590013.pdf

3. Silva LM, Bueno CD. Adherence to dietary treatment from the perspective of patients with chronic renal failure on hemodialysis. Nutrire[Internet]. 2014[cited 2015 Jun 10];39(3):276-83. Available from: http://files.bvs.br/upload/S/1519-8928/2014/v39n3/a4561.pdf

4. Herdman TH. NANDA International Nursing Diagnoses: definitions and classification 2012-2014. Oxford: Wiley-Blackwell; 2012.

5. Silva FBBL. Análise de conceito do diagnóstico de enfermagem autocontrole ineficaz da saúde em pacientes submetidos à hemodiálise[Dissertação]. Universidade Federal do Rio Grande do Norte; 2014.

6. Lata AGB, Albuquerque JG, Carvalho LASBP, Lira ALBC. Nursing diagnosis in adults on hemodialysis. Acta Paul Enferm[Internet]. 2008[cited 2017 May 05];21(Esp):160-63. Available from: http://www.scielo.br/pdf/ape/v21nspe/a04v21ns 
7. Holanda RH, Silva VM. Nursing diagnosis of patients in treatment of hemodialysis. Rev. Rene[Internet]. 2009 [cited 2017 May 05];10(2):37-44. Available from: http://repositorio.ufc.br/bitstream/riufc/13647/1/2009_art_rholanda.pdf

8. Costa AGS, Santos RMB, Vitor AF, Araujo TL. Nursing diagnosis of patients in treatment of hemodialysis in teaching hospital. Rev Enferm UFPE[Internet]. 2010[cited 2017 May 05];4(3):1477-483. Available from: http://www.revista.ufpe.br/revistaenfermagem/ index.php/revista/article/view/1047

9. Brasil. Ministério da Saúde. Resolução № 466, de 12 de dezembro de 2012. Diário oficial da União. Poder executivo. Brasília, DF; 2012.

10. Frazão CMFQ. Validação do conteúdo do diagnóstico de enfermagem proteção ineficaz em pacientes submetidos à hemodiálise[Tese]. Universidade Federal do Rio Grande do Norte; 2015.

11. Pompeo DA, Rossi LA, Paiva L. Validação de conteúdo do diagnóstico de enfermagem náusea. Rev Esc Enferm USP[Internet]. 2014[cited 2015 Jun 21];48(1):49-57. Available from: http://www.scielo.br/pdf/reeusp/v48n1/pt_0080-6234-reeusp-48-01-48.pdf

12. Chaves ECL, Carvalho EC, Hass VJ. Validação do diagnóstico de enfermagem Angústia espiritual: análise por especialistas. Acta Paul Enferm[Internet]. 2010[cited 2015 Jun 20];23(2):264-70. Available from: http://www.scielo.br/scielo. php?script=sci_arttext\&pid=S0103-21002010000200018\&lng =en

13. Galdeano LE, Rossi LA. Validação de conteúdo diagnóstico: critérios para seleção de expertos. Ciênc Cuid Saúde[Internet]. 2006[cited 2015 Jun 20];5(1):60-6. Available from: http://www.periodicos.uem.br/ojs/index.php/CiencCuidSaude/article/view/5112

14. Costa KPS. Adesão de pacientes portadores de insuficiência renal crônica à terapia dialítica[Monografia]. Recife, PE: Universidade Paulista e Centro de Consultoria Educacional, Programa de pós-graduação em nefrologia; 2012.

15. Madeiro AC, Machado PDLC, Bonfim IM, Braqueais AR, Lima FET. Adesão de portadores de insuficiência renal crônica ao tratamento de hemodiálise. Acta Paul Enferm[Internet]. 2010[cited 2015 Jun 20];23(4). Available from: http://www.scielo.br/pdf/ ape/v23n4/16.pdf

16. Yodchai K, Dunning T, Hutchinson AM, Oumtanee A, Savage S. How do Thai patients with end stage renal disease adapt to being dependent on haemodialysis? a pilot study. J Renal Care[Internet]. 2011[cited 2015 Jun 22];37(4). Available from: http://dx.doi. org/10.1111/j.1755-6686.2011.00232.x

17. Frazão CMFQ, Bezerra CMB, Nunes MGM, Lira ALBC. Changes in the self-concept mode of women undergoing hemodialysis: a descriptive study. O Braz J Nurs[Internet]. 2014[cited 2015 Jun 22];13(2):215-22. Available from: http://www.objnursing.uff.br/ index.php/nursing/article/view/4209

18. Nunes FA, Nunes SA, Lorena IG, Novo NF, Juliano Y, Schnaider TB. Autoestima, depressão e espiritualidade em pacientes portadores de doença renal crônica em tratamento hemodialítico. Rev Med Res[Internet]. 2014[cited 2015 Jun 22];16(1):18-26. Available from: http://crmpr.org.br/publicacoes/cientificas/index.php/revista-do-medico-residente/article/view/527/512

19. Pessoa NRC, Linhares FMP. Pacientes em hemodiálise com fístula arteriovenosa: conhecimento, atitude e prática. Esc Anna Nery Rev Enferm[Internet]. 2015[cited 2015 Jun 22];19(1):73-9. Available from: http://www.scielo.br/pdf/ean/v19n1/1414-8145ean-19-01-0073.pdf

20. Sgnaolin V, Figueiredo AEPL. Adesão farmacológica de pacientes em hemodiálise. J Bras Nefrol[Internet]. 2012 [cited 2015 Jun 23];34(2):109-16. Available from: http://www.scielo.br/pdf/jbn/v34n2/02.pdf

21. Bastos MG. Interação medicamentosa na doença renal crônica. J Bras Nefrol[Internet]. 2014[cited 2015 Jun 23];36(1):8-9. Available from: http://www.scielo.br/pdf/jbn/v36n1/0101-2800-jbn-36-01-0008.pdf

22. Beuter M, Muller LR, Brondani CM, Pauletto MR, Timm AMB, Perlini NMOG. A adesão de indivíduos em terapia dialítica. Rev Pesq: Cuid Fundam[Internet]. 2013[cited 2015 Jun 23];5(2):3558-66. Available from: http://www.seer.unirio.br/index.php/ cuidadofundamental/article/view/2147/pdf_716

23. Guedes KD, Guedes HM. Qualidade de vida do paciente portador de insuficiência renal crônica. Rev Ciência Saúde[Internet]. 2012[cited 2015 Jun 23];5(1):48-53. Available from: http://revistaseletronicas.pucrs.br/ojs/index.php/faenfi/article/view/9734/7746

24. Silva AS, Silveira RS, Fernandes GFM, Lunardi VL, Backes VMS. Percepções e mudanças na qualidade de vida de pacientes submetidos à hemodiálise. Rev Bras Enferm[Internet]. 2011 [cited 2015 Jun 23];64(5). Available from: http://www.scielo.br/pdf/ reben/v64n5/a06v64n5.pdf 